\title{
Macroeconomics And Bank-Specific Factors Affecting Liquidity: A Study Of Nepali Commercial Banks
}

\author{
Pushpa Raj Ojha, PhD Scholar \\ Asst. Campus Chief \\ Nepal Commerce Campus, T.U \\ pushpa@ncc.edu.np
}

\begin{abstract}
This paper aims to examine the form and pattern of liquidity, $N P L$, return on assets, CAR, return on equity, GDP, inflation and interbank rate in Nepalese commercial banks. The study is intended to analyze the relationship between liquidity and bank specific variables in Nepalese commercial banks. The key findings stated that there is significant relation between numbers of variables that impacts on the liquidity performance of Nepalese commercial banks. The panel data of commercial banks from 2010/11 to 2016/17 has been taken for the purpose of the research. Mean, standard deviation, correlation and multiple regression analysis have been used to diagnose date to meet the specific objectives of research. The results reveal that there is significant influence of ROA, ROE, NPL, GDP and IBR on LIQ.
\end{abstract}

Keywords: Return on assets, Return on equity, Non-performing loans, Capital adequacy ratio and Inter-bank rate

\section{Introduction}

Liquidity for a bank means the ability to meet its financial obligations as they come due. Bank lending finances investments in relatively illiquid assets, but it funds its loans with mostly short term liabilities. Thus one of the main challenges to a bank is ensuring its own liquidity under all reasonable conditions. A bank's liquidity is determined by its ability to meet all its anticipated expenses, such as funding loans or making payments on debt, using only liquid assets. The attention has been paid by lender to the last resort to overcome the liquidity crisis (Aspachs, Nier, Tiesset, 2005). Vodova (2014) showed that a bank specific and macroeconomic variable affects the bank liquidity. After the global financial crisis, bank has begun to examine the problems of liquidity and its importance to the overall performance of the banking sector and financial markets. The world economy 
has experienced a number of financial crises. These crises are issues of liquidity provision by the banking sector and a financial market. When crises are likely to arrive, bank seem less willing to lend and hold more liquidity due to the low level of liquidity in the market for external finance. Berger and Bouwman (2009) found the connection between financial crises and bank liquidity creation.

Bank specific factors or internal factors are the individual bank characteristics, which affect bank performance. These factors are influenced by the internal decisions of management and board. These factors are also within the scope of the bank to manipulate them and they differ from bank to bank. These include capital, size of deposit liabilities, size, and composition of credit portfolio, interest rate policy, labor productivity, and state of information technology, risk level management quality, bank size, and ownership among others (Dang, 2011). The liquidity ratio as a measure of bank's liquidity assumed to be dependent on individual behaviour of banks, their market and macroeconomic environment and the exchange rate regime, i.e. on following factors: total assets as a measure of the size of the bank (-), the ratio of equity to assets as a measure of capital adequacy (+), the presence of prudential regulation, which means the obligation for banks to be liquid enough $(+)$, the lending interest rate as a measure of lending profitability $(-)$, the share of public expenditures on gross domestic product as a measure of supply of relatively liquid assets (+), the rate of inflation, which increases the vulnerability of banks to nominal values of loans provided to customers (+), the realization of a financial crisis, which could be caused by poor bank liquidity (-), and the exchange rate regime, where banks in countries with extreme regimes (the independently floating exchange rate regime and hard pegs) were more liquid than in countries with intermediate regimes. Most studies conducted in relation to bank performances focused on sector-specific factors that affect the overall banking sector performances (Chantapong, 2005). Nevertheless, there is a need to include the macroeconomic variables. Thus, this study has incorporated key macroeconomic variables (Inflation and GDP) in the analysis. Moreover, this study examined whether ownership identity has influenced the relationship between bank specific factors, macro-economic indicators on liquidity of Nepalese commercial banks.

It is well known facts that currently banks and financial intuitions in Nepal have been facing the problem of liquidity and the issue is becoming difficult to manage. Though, many studies have been taken place in order to find out the impact of bank specific and macroeconomic factor on liquidity in international scenario. But, there is no exclusive study on bank specific and macroeconomic determinant of liquidity in case of Nepalese banking scenario. So, this study attempts to fulfill the gap to certain limits. This study will help for the further studies carried out in countries like Nepal. This study also contributes to the financial sectors of the economy and society. Therefore, the major beneficiaries from this study are commercial bank, regulatory bodies, the academic staff and society.

Liquidity creation itself is seen as the primary source of economic welfare contribution by banks but also as their primary source of risk' (see: Bryant, 1980; Diamond \& Dybvig, 1983). Therefore, virtually every financial transaction or commitment has implications for a bank's liquidity. For instance, as United States/U.S. subprime mortgage 
crisis reached its peak in the years 2008/9 unprecedented levels of liquidity support were required from central banks in order to sustain the financial system. A reduction in funding liquidity then caused significant distress. In response to the freezing up of the interbank market, the European Central Bank and U.S. Federal Reserve injected billions in overnight credit into the interbank market. Some banks needed extra liquidity supports (Bernanke 2008). It is evident that liquidity and liquidity risk is very up-to-date and important topic. Therefore banks and more so their regulators are keen to keep a control on liquidity position of banks.

Banks should have ready access to immediately expendable funds at reasonable cost precisely at the time those funds are needed. Lack of adequate liquidity is often is often one of the first signs that a bank is in serious financial trouble. The commercial banks are a major player in Nepalese banking sector and financial services industry. Aryal (2010) indicated that the profitability rate, operating expenses, dividend distribution among the shareholders etc. have been found inconsistent. There must be some reasons behind such differences in performance, the problem of the study refers to the liquidity and profitability analysis of JVBs. Subba (2006) revealed the gap analysis is the major tool for managing the liquidity risk. Manandhar (2004) stated that the liquidity position of all bank is very higher and commercial bank prefer to invest in short term loans and securities. Maharjan et al. (2016) examined the relationship between bank credit risk, profitability and liquidity of commercial banks in Nepal. The study concluded that major determinants of credit risk, profitability and liquidity of Nepalese commercial banks are non-performing lon, loan to deposit and lesser prudence. Bhusal (2016) found the impact of liquidity position on the buffer of regulatory capital.

\section{Literature Review}

Rychtarik (2009) and Praet \& Herzberg (2008) have also provided similar understandings with liquidity ratios such as liquid assets to total assets, liquid assets to deposits and short term financing, loans to total assets and loans to deposits and short term borrowings as cited in (Vodova, 2011) are the determinants of commercial bank' liquidity in hungary. In short, the liquidity ratio carries varies balance sheet ratios to identify liquidity needs (Crosse \& Hempel 1980, \& Vodova 2011). Diamond and Dybvig (1983) emphasize the "preference for liquidity" under uncertainty of economic agents to justify the existence of banks: banks exist because they provide better liquidity insurance than financial markets. However, as banks are liquidity insurers, they face transformation risk and are exposed to the risk of run on deposits. More generally, the higher is liquidity creation to the external public, the higher is the risk for banks to face losses from having to dispose of illiquid assets to meet the liquidity demands of customers. A natural justification for the existence of deposit-taking institutions, thereby giving also an explanation for the economically important role of banks in providing liquidity, was initially modeled by Bryant (1980) and Diamond \& Dybvig (1983).

Diamond \& Raghuram (2000) advocate that Banks capital creates liquidity for the bank due to the fact that deposits are most fragile and prone to bank runs. Moreover, 
greater bank capital reduces the chance of distress. However, it is not without drawbacks that it induce weak demand for liability, the cheapest sources of fund Capital adequacy is the level of capital required by the banks to enable them withstand the risks such as credit, market and operational risks they are exposed to in order to absorb the potential loses and protect the bank's debtors. Capital adequacy ratio shows the internal strength of the bank to withstand losses during crisis. Capital adequacy ratio is directly proportional to the resilience of the bank to crisis situations (Dang, 2011, and Al-Khouri, 2012).

Nishanthini and Meerajancy (2015) analyzed the tradeoff between liquidity and profitability with the samples of state bank and private bank in Sir Lanka over period of 2008-2012. There is an insignificant correlation between liquidity and profitability in both state banks and private banks. The regression results showed negative impact of liquidity on profitability in selected banks in Sir Lanka. The study concluded that bank having the higher level of liquidity would have lower level of profitability. Alshatti (2015) investigated the effect of the liquidity management on profitability in the 13 Jordanian commercial banks during the time period of 2005-2012. By utilizing the data of the annual reports of the Jordanian commercial banks, which issued by Amman Stock Market, to be in the form of panel study type since this type of studies dealing with the same people, groups or organizations across multiple time periods. Augmented Dickey Fuller (ADF) stationary test model was used to test for a unit root in a time series of the research variables and then testing hypothesis by using regression analysis and study also used two regression model and first model measures the effect of the liquidity management indicators on profitability in the Jordanian commercial banks, where return on equity (ROE) was the proxy for profitability.

\section{Objective}

To analyze the macroeconomic and bank specific factors affecting liquidity in Nepali commercial banks.

\section{Research Methodology}

Research designs namely descriptive and causal comparative have been used for the purpose of the study. This study has employed descriptive research design to deal with the fact-finding and searching adequate information associated with explanatory variables and liquidity of Nepalese commercial banks. In addition, causal comparative research design has been used to analyze the cause and effect relationship between the explanatory variables and bank liquidity. Causal comparative approach has adopted to establish the directions, magnitudes and forms of the observed relationship between liquidity and other independent variables .Causal-comparative research, like correlational research, seeks to identify associations among variables and regression analysis has been conducted. The casual comparative research design helps to ascertain and understand the directions magnitudes and form of observed relationship between bank specific and macroeconomic factor and liquidity.

Household Sampling and Sample Size 
In order to analyze the impact of bank specific and macroeconomic determinant of liquidity buffer the data were collected from various sources like Nepal Rastra bank website, World Bank websites and Global economy websites. There are many idiosyncratic and macroeconomic variables that have significant effect on liquidity but due to the lack of availability of data these variables have been used. This study is based on secondary source of data. This study focuses on bank specific and macroeconomic determinant of liquidity of 15 commercial banks of Nepal and consists of 8 years data.

The study is based on the secondary data which are gathered for 15 commercial banks in Nepal for the period of 7 years from 2009/10 to 2016/17. As categorized into bank specific variable (ROA, ROE, NPL,CAR) and macroeconomic variable (GDP, inflation, Interbank Rate) are used in this study. Banking and Financial Statistics, Quarterly Economic Bulletin and Bank Supervision Report published by Nepal Rastra Bank and Annual Reports of the selected commercial bank are the major sources of the issue.

\section{Data Analysis}

Model Specification

The main objective of data analysis is to analyze the magnitude and direction of the effects of idiosyncratic and macroeconomic variable on liquidity in the case of Nepalese commercial banks. Thus, this section deals with statistical and econometric models used for the purpose of analysis of secondary data. The methods of data analysis used in this study have been divided into two subsections. First section deals with the methods of secondary data analysis. This includes descriptive statistics, correlation analysis and regression analysis. Second section describes different statistical test for significance for validation of model such $\mathrm{t}$-test and F-test.

The regression model is used in this study in order to analyze the effect of idiosyncratic and macroeconomic effect on liquidity. The effects of idiosyncratic and macroeconomic variable on liquidity of Nepalese commercial banks were analyzed by computing regression equations. The relationship between dependent and independent variables can be stated in the following form:

The model is specified assuming the liquidity is the function of bank specific variables, macro-economic variables. More specifically:

Liquidity $=f$ (bank specific variables, macro- economicvariables) Defining the respective variables, model (1) can be written as Liquidity $=f(R O A, R O E, N P L, C A R, G D P$, INF, IBR)

\section{Model 1}

$L Q$ it $=\beta 1+\beta 2 R O A$ it $+\beta 3 R O E$ it $+\beta 4 N P L$ it $+\beta 5 C A R$ it $+\beta 6 G D P t+\beta I B R t+e i t$

LQ1 it $=$ Ratio of liquid assets to total assets

ROAit $=$ Return on assets

ROE it = Return on equity

$N P L$ it $=$ Non performing loan

CAR it = Capital adequacy ratio 
GDP $t=$ Gross domestic profit

$\mathrm{IBRt}=$ Inter bank rate

Descriptive Statistics Analysis

Table 1

Descriptive Statistics

\begin{tabular}{ccccc}
\hline Variable & Min & Max & Mean & SD \\
\hline LQ & 0.12 & 0.68 & 0.42 & 0.08 \\
ROA & -1.01 & 8.97 & 1.75 & 1.02 \\
ROE & -6.89 & 47.84 & 17.83 & 7.74 \\
NPL & 0.12 & 19.75 & 2.15 & 2.17 \\
CAR & 10.52 & 19.94 & 12.65 & 1.84 \\
GDP & 2.85 & 7.89 & 4.87 & 1.54 \\
IBR & 0.26 & 8.98 & 3.54 & 3.18 \\
\hline
\end{tabular}

The mean values of variable have found to be ranging from 0.442 to 17.83 where as the standard deviation have recorded to be ranging from 0.08 to 7.74 . Likewise, minimum values have recorded to be -1.01 to 10.52 and maximum values have obtained to be ranging from 0.68 to 47.84 .

Correlation Co-efficient between Dependent and Independent Variable

The table 2 shows that the correlation between dependent and independent variables. The LQ is the dependent variable and ROA, ROE, NPL, CAR, GDP and IBR are the independent variables taken under investigation.

Table 2

Correlation Co-efficient between Dependent and Independent Variable

\begin{tabular}{cccccccc}
\hline Variable & LQ & ROA & ROE & NPL & CAR & GDP & IBR \\
\hline LQ & 1.00 & & & & & & \\
ROA & 0.00 & 1.00 & & & & & \\
ROE & -0.11 & 0.87 & 1.00 & & & & \\
NPL & -0.02 & -0.09 & -0.05 & 1.00 & & & \\
CAR & 0.17 & 0.27 & -0.20 & 0.21 & 1.00 & & \\
GDP & 0.05 & 0.06 & 0.09 & -0.08 & -0.07 & 1.00 & \\
IBR & -0.11 & 0.10 & 0.09 & 0.11 & 0.09 & -0.35 & 1.00 \\
\hline
\end{tabular}


The correlation coefficients between LIQ and ROA, ROE, NPL, CAR, GDP and IBR have recorded to have significant. The result shows that there is significant relationship between dependent variable and independent variables under investigation.

Multiple Regression Analysis

Table 3

Multiple Regression Analysis

\begin{tabular}{cccl}
\hline Variable & Beta & t value & p value \\
\hline ROA & -0.214 & -21.073 & $0.000 * *$ \\
ROE & -0.225 & -16.87 & $0.000 * *$ \\
NPL & -0.215 & -32.544 & $0.000 * *$ \\
CAR & 0.165 & 4.773 & $0.000 * *$ \\
GDP & 0.191 & 13.805 & $0.000 * *$ \\
IBR & -0.224 & -4.528 & $0.000 * *$ \\
\hline
\end{tabular}

The asterisk (*) sign indicates that result is significant at $5 \%$ level and double asterisk $(* *)$ sign indicates that result is significant at $1 \%$.

The results are based on panel data of commercial banks for the period of 2010/10 to $2016 / 17$ by using linear regression model. The model is, $L Q$ it $=\beta 1+\beta 2 R O A$ it $+\beta 3 R O E$ it $+\beta 4 \mathrm{NPL}$ it $+\beta 5 \mathrm{CAR}$ it $+\beta 6 \mathrm{GDPt}+\beta 7$ IBRt+eit. LQ1 is Liquid assets to total assets in times is dependent variables and the independent variables are ROA (return on assets defined as net income to total assets, in percentage) , ROE (return on equity defined as net income divided by total shareholders' equity in percentage) , NPL (ratio of nonperforming loan to total loan) ,CAR (capital adequacy ratio defined as sum of tier I and tier II capital to risk weighted assets),GDP (GDP is defined as annual growth rate of domestic product in percent), INF (inflation rate defined as the rise in general price level of goods and services, in percentage, IBR(short term interest rate between banks). Table 3 shows that the negative beta coefficient for return on assets, return on equity. This result also indicates that higher the return on assets, lower would be the liquid assets by total assets which is significant at 5 percent level of significance. This study shows the positive relationship for capital adequacy ratio and GDP, inflation with LQ1 (liquid assets by total assets). This indicates that higher the capital adequacy ratio higher would be the liquid assets by total assets which is significant at 5 percent level of significance.

\section{Conclusion and Discussion}

The findings reveal that there is significant influence of ROA, ROE, NPL, CAR, GDP and IBR on LIQ. The major conclusion of the study is return on equity, return on assets, non-performing loan, interbank rate have negative impact on the liquidity of Nepalese commercial banks indicating that higher the return on equity, return on assets, nonperforming loan, interbank rate, lower the LQ. The study also concludes that Capital 
Adequacy Ratio, Gross Domestic Product and inflation have positive impact on liquidity of Nepalese commercial banks indicating that higher the Capital Adequacy Ratio, Gross Domestic Product and inflation, higher will be the LQ.

The result reveals that there is significant influence of ROA on LIQ. This finding is consistent with the findings of Almumani (2013). Also, higher the return on equity, lower the liquid assets by total assets. This result was consistent with findings (Saleem \& Rehman, 2011). The study also reveals that negative beta coefficient for non-performing loan. This indicates that higher the non-performing loan lower would be the liquid assets by total assets. This finding is consistent with the findings of (McNulty, Akhigbe, \& Verbrugge, 2001). This finding is consistent with the findings of (Iqbal, 2012). The positive beta coefficient of GDP indicates that higher the GDP, higher would be the liquid assets by total assets. This finding is consistent with the findings of (Bunda \& Desquillbet, 2008). Also, the finding indicates there is positive realtionship between inflation and LQ1. This result is consistent with the findings of (Tseganesh, 2012). The study also reveals that negative beta coefficient interbank rate with $L Q$ (liquid assets by total assets). This result also indicates that higher the interbank rate lower would be the liquid assets by total assets. This finding is consistent with the findings of (Joshi, 2016).

\section{References}

Al-Khouri, R. (2012). Bank characteristics and liquidity transformation: The case of GCC banks.

International Journal of Economics and Finance, 5(12), 114-120.

Almumani, M. A. (2013). Impact of managerial factors on commercial bank profitability: Empirical evidance from Jordan. International Journal of Academic Research in Accounting, Finance and Management Sciences, 3(3), 298-310.

Alshatti, A. S. (2015). The effect of the liquidity management on profitability in the jordanian commercial banks. International Journal of Business and Management, 10(1), 62-72.

Aryal , B. (2010). Relationship between liqudity and profitablity of jont venture bank in Nepal.

Aspachs, O, Nier, E and Tiesset, M 2005, „Liquidity, Banking Regulation and the Macroeconomy: Evidence on bank liquidity holdings from a panel of UK-resident banks, Bank of England Working Paper.

Bernanke, B. (2008). Liquidity Provision by the Federal Reserve, Risk Transfer Mechanisms and Financial Stability Workshop. Switerzland.

Bhusal, V. (2016). Bank regulatory capital buffer and liquidity: A case of Nepalese commercial banks. Nepalese Journal of Management , 3 (3), 151-162.

Bunda, I., \& Desquillbet, J. B. (2008, September). The bank liquidity smile across exchange rate regimes. International Economic Journal,, 22(3), 361-386.

Bryant, J. (1980). A model of reserves, bank runs, and deposit insurance. Journal of Banking nad Finance, 4, 335-344.

Chantapong, S. (2005). Comparative Study of Domestic and Foreign Bank Performance in Thailand: The Regression Analysis. The Office of Macroeconomic Poplicy and 
Analysis, Monetary POlicy Group(MPG), The Central Bank Of Thailand, Bangkhuprom. Retrieved 2005

Crosse, H., \& Hempel, G. (1980). Management Policies for Commercial Banks, (3rd ed.). (E. Cliffs, Ed.) New Jersey: Prentice Hall Inc.

Dang, U. (2011). The CAMEL Rating System in Banking Supervision: A Case Study of Arcada University of Applied Sciences. In International Business.

Diamond, D. W., \& Dybvig, P. H. (1983). Bank runs, deposit insurance, and liquidity. Journal of Political Economy, 105(91), 401-419.

Diamond, D. W., \& Raghuram, A. (2000). A Theory of Bank Capital. The journal of Finance, 52(6), 12-23.

Iqbal, A. (2012). Liquidity risk mangement : A comparative study between conventional and Islamic of Pakistan. Global Journal of Management and Business Research, 12(5), 54-64.

Joshi, A. (2016). ). Idiosyncratic and macroeconomic determinants of liquidity : A case of Nepalese commercial bank. Nepalese Journal of Business, 3(3), 103-115.

Maharjan , A., Yadav, A., Poudel, B., Shrestha, B., \& Aryal, B. (2016). The relationship between bank credit,liquidity and profitability in Nepalese commercial banks. Nepalese Journal

of Management, 3 (1), 157-169.

Manandhar, R. (2004). Problem and prospects of commercial banking sectors in relation to deposit mobilization, An unpublished thesis, central department of management, Tribhuvan University.

McNulty, J., Akhigbe, A., \& Verbrugge, J. (2001). Small bank loan quality in a deregulation environment: The information advantage hypothesis. Journal of Economics and Business, 53(2), 325-339.

Praet, P., \& Herzberg, V. (2008). Market liquidity and banking liquidity: linkages, vulnerabilities and the role of disclosure. In Banque de France Financial stability Review. Banque de France, 95-109.

Rychtarik, S. (2009). Liquidity Scenario Analysis in the Luxembourg Banking Sector. Banque Centrale du Luxembourg, 41.

Saleem, S., \& Rehman, S. (2011). Liquidity Management and Commercial Banks' Profitability.

Journal of Economics and Management, 226-241.

Subba, S. (2006). Risk management of commercial bank in Nepal : A comparative study between NCC bank Itd. and NBB bank Itd. Kathmandu: An unpublished master degree thesis, central department of mangement T.U.

Tseganesh, T. (2012). Determinants of bank liquidity and their impact on financial performance.

Journal of Finance, 58(1), 33-74.

Vodova, P. (2014). Determinants of commercial banks' liquidity in Poland. International Conference Mathematical Methods in Economics, 5, 180-187. 